
http://dx.doi.org/10.33474/j-reall.v2i1.9524

Volume 2 | Number 1 | p. $68-75$ Published on January 19th 2021

\title{
The elimination of anticipated written errors from L1 interference through flipped classrooms
}

\author{
Napacha Prapawadee \\ Prince of Songkla University, Phuket Campus, Thailand \\ napacha.p@phuket.psu.ac.th \\ *) correspondence: napacha.p@phuket.psu.ac.th
}

\begin{abstract}
Several studies have been conducted on written errors discovered in an EFL classroom, and the findings are similar, and that common errors have been discovered in Thai students' written work, so these studies conclude that the main cause of errors is L1 interference. In addition, other related studies reveal that flipped classrooms can support students' learning process. It is due to the fact that these days, EFL students still have problems with some grammatical aspects due to their mother tongue, and the class time provided is limited. Therefore, to ascertain that the flipped classroom can help eliminate the anticipated grammatical problems repeatedly in class; the study looks to develop online lessons on LMS to encourage the students to learn at their own pace and to engage students with class activities. The online lessons and class activities are currently being implemented, and 25 freshmen participate in this study. The questionnaire will be completed at the end of the semester to discover their attitudes towards the flipped classroom covering online lessons and class activities. Also, a pre-test and post-test on simple sentences are used to investigate the students' learning outcomes via the flipped classroom. The findings from the pre- and post-tests confirm the results of the former studies that the students produce the anticipated errors such as articles, capitalization, punctuation, nouns, and subject-verb agreement. Also, synchronous and asynchronous learning can help eliminate those mentioned errors and the students have positive attitudes towards the flipped classroom.
\end{abstract}

Keywords: written errors; L1 interference; flipped classroom

\section{INTRODUCTION}

English is considered as a significant foreign language in Thailand since it is compulsorily taught in school at all three education levels: primary, secondary, and tertiary levels. All Thai university students have been studying English for more than 10 years; however, their English proficiency is very low. According to the Ministry of Education in Thailand, it reveals that the English proficiency of Thai students has been dropping since 2017: 49.7 in 2017, 48.54 in 2018, and 47.61 in 2019 based on the annual English Proficiency Index presented by the global education company EF (Education First). The score of 47.61 is regarded "very low proficiency", and Thailand ranked the sixth in southeast Asian countries with Singapore at the top (MoE, 2019).

In Thailand, students are required to have basic education for nine years: six years in primary school and the first three years in lower-secondary school. Also, students can further their study for another three years to complete upper-secondary school or vocational college. Based on basic education in Thailand, all students start studying English in Prathom 1 (Grade 1). To promote English in education, the Thai Ministry of Education sets the targets for Thai students' English proficiency in line with the Common European Framework of Reference for Languages or CEFR levels (A1 - C2: A1 and A2 levels are basic users, B1 and B2 levels are independent users, and C1 and C2 levels are proficient users). Consequently, by the end of Prathom 6 (Grade 6), students should reach an A1 
level. In addition, for those students who complete junior high school (Grade 9), they should reach an A2 level. Besides, students who graduate from high school (Grade 12) or vocational college should reach at least a B1 level (British Council, 2016 cited in Kanchai, 2019 and Kaewwichian and Jaturapitakkul, 2018).

At a tertiary level, consequently, freshmen's English proficiency should be at a B1 level or above. In fact, at a university level, Waluyo (2019) found that the majority of freshmen were basic users (at A1 and A2 levels); however, these levels were for those students of primary and junior high school in the Thai education system. In short, not all of the university students in Thailand achieve CEFR level B1 or higher as expected although they have been studying English for at least 12 years on average.

\section{Written Errors due to L1 Interference}

In an EFL classroom which primarily aims to develop students' writing ability, written errors from students' work are useful for teachers to identify the causes of errors and to assist teachers to prepare teaching materials and class activities. Several studies have been conducted on written errors discovered in an EFL classroom in Thailand, and the findings are similar, and that common errors have been found repeatedly in Thai students' written work. Prapawadee (2005: 8-9) analyzed the studies related to students' written errors and she found that the most frequent errors were grammatical ones such as articles, tenses, prepositions, and subject-verb agreement. In addition, the main causes of errors are language transfer and overgeneralization. In addition, Bennui (2008) studied students' errors focusing on L1 interference at word, sentence, and discourse levels. He found that Thai words were used in English written work due to literal translation, and these reflected L1 lexical interference. Furthermore, errors about word order, subject-verb agreement, and noun determiners were discovered, and these errors were also due to L1 syntactic interference. Moreover, Sittirak (2015) applied the Grammar-Translation Method to study the students' work and to analyze the difficulties in the students' translation at sentence level. She also found that students made errors at both word and sentence levels such as preposition, pronoun, adverb, and noun. Besides, the current studies focusing on written errors from students' written work conducted by Roongsitthichai et al. (2019), they also revealed that errors made by the students at the sentential level were capital letter, punctuation, subject-verb agreement, run-on, fragment, word order, and tense. At the word level, the errors covered word choice, preposition, noun, and article. In the initial stage of language learning process, patterns from the first language are borrowed and used in the learned foreign language. L1 patterns or rules which lead to errors or inappropriate forms in the target language are negative transfer or L1 interference (Richards and Schmidt, 2010: 322-323).

\section{Flipped Classrooms}

Flipped classrooms can be another way to support students' learning process. It is due to the fact that these days, EFL students in Thailand still have problems with some grammatical aspects due to their mother tongue although they have been learning the target language for over 10 years, and the class time provided is also limited. A flipped classroom is the combination of synchronous learning and asynchronous independent study. In real time of synchronous learning, students can learn either in class or in a virtual classroom online. They can interact with their classmates and a teacher and get instant feedback. In addition to synchronous learning, asynchronous learning is also provided via digital platform so that content can be accessed from anywhere at any time, so students can learn independently at their own pace (Peachey, 2020). Additionally, in the 21 st century, as for the concept of a flipped classroom, it is for students to study lessons through various means, especially via technology at home and then students have more time to do homework or participate activities in class (Sitsungnern, 2017).

As for research related to flipped classrooms in Thailand, Thaichay and Sitthitikul (2016) investigated the effects of flipped classroom instruction on language accuracy and active learning environment. They found that the flipped classroom can help improve students' English language accuracy in the EFL classroom, and can help promote an active learning environment in teaching English grammar. Also, students have positive attitude towards the flipped classroom. Besides, Srichailard and Srichailard (2019) conducted their research to investigate the effectiveness of flipped 
classrooms with think-pair-share and project-based learning, and they found that the model of the flipped classrooms they developed was effective that the students performed more effectively after the semester.

Therefore, to ascertain that the flipped classroom can help eliminate the anticipated grammatical problems repeatedly due to L1 interference in an EFL class; the study looks to develop online lessons on LMS to encourage the students to learn asynchronously at their own pace and to engage students with class activities synchronously.

This study aims to investigate whether the flipped classroom applied in an EFL classroom can help eliminate written errors from L1 interference, and whether it affects students' attitudes towards the flipped classroom. The study attempts to answer the following research questions:

1. Does the flipped classroom help eliminate anticipated written errors from L1 interference?

2. What are students' attitudes towards the flipped classroom?

It is expected that the students might have a more positive attitudes towards the flipped classroom involving both classroom activities and online lessons, and their attitudes might lead to better learning outcomes with less written errors from L1 interference.

\section{METHODS}

This study has been conducted both quantitatively and qualitatively. The design and procedures of the study for research methodology are divided into four sections: subjects of the study, research instruments, data collection, and data analyses and statistical devices.

The subjects participating in this study were 25 freshmen taking English for Fundamental Reading and Writing due to a curriculum requirement of the faculty of International Studies, Prince of Songkla University, Phuket Campus in the first semester of the academic year 2020. According to the placement test, this group of students is considered as a basic user (A1 and A2 levels) showing that their English proficiency does not reach the curriculum requirements, so they have to brush up on their English in order to get ready for an international curriculum in their first semester of their study in the university.

As for a synchronous study, the students participate in class activities two hours a week on Mondays throughout the semester. Also, they learn the content on their own through Learning Management System or LMS asynchronously. In order to obtain information for the study, the preand post- tests, online lessons, class activities, and questionnaire were used.

Pre-test and post-test are identical. They were designed in accordance with the objectives of the lesson "simple sentence with verb to be". They were controlled writing tests with grammartranslation method to check students' grammatical patterns, sentence structure, punctuation, and word order. The tests were used to determine the students' performance in sentence writing; to see if they produce less anticipated written errors such as capitalization, punctuation, articles, and subject-verb agreement. The tests have been reviewed and developed by five Thai lecturers of English. The objectives of the lessons are set in line with the anticipated written errors due to L1 interference, so by the end of the lessons, the students will be able to...

1. form a simple sentence with the structure $\mathrm{S}+$ be $[$ is $/$ am/are $]+\ldots$

2. capitalize the first word of the sentences and all proper nouns.

3. use correct punctuation focusing on a period at the end of the sentence.

4. apply subject-verb agreement rules.

5. understand the usage of 'be' in English.

6. use correct determiners with nouns.

The following are three examples of 30 test items that the students have to translate Thai simple sentences into English ones with verb to be.

TABLE 1. Thai Simple Sentence

\begin{tabular}{ll}
\hline เขาป่วย & \\
\hline เขา & ป่วย \\
\hline$/ \mathrm{k}^{\mathrm{h}} \mathrm{aw} /$ & $/$ pùaj/ \\
\hline
\end{tabular}


3-SG-M Sick

He is sick.

The anticipated written errors can be predicted from the above sentence เขาป่วย from L1 interference that a capital letter in the first word of the sentence and a period at the end of the sentence might be ignored. In addition, 'be' might be omitted because ป่วย functions as a verb in Thai, but an adjective in English.

TABLE 2. Language Interference 1

\begin{tabular}{|c|c|c|}
\hline \multicolumn{3}{|c|}{ เธอเป็นเลขาฯ } \\
\hline เธอ & เป็น & เลขาฯ \\
\hline$/ \mathrm{t}^{\mathrm{h}} \bar{\gamma}: /$ & $/ \mathrm{pen}^{-} /$ & /lē.knă.nú.kāan/ \\
\hline 3-SG-F & $\mathrm{COP}$ & secretary \\
\hline
\end{tabular}

From the above test item, the article 'a' before a noun 'secretary' might be omitted because there are no articles in Thai.

TABLE 3. Language Interfence 2

\begin{tabular}{llllll}
\hline เล็กและใหญ่เป็นเพื่อนกัน & & & & \\
\hline เล็ก & และ & ใหญ่ & เป็น & เพื่อน & กัน \\
\hline$/$ lék & $/$ lé $/$ & $/ \mathrm{jàj} /$ & $/ \mathrm{pen} /$ & $/ \mathrm{p}^{\mathrm{h}} \hat{\mathrm{uan}} /$ & $/ \mathrm{kān} /$ \\
\hline Name-Lek & and & Name-Yai & COP & friend & REC \\
\hline
\end{tabular}

Lek and Yai are friends.

Possible errors from เล็กและใหญ่เป็นเพื่อนกัน can be about subject-verb agreement and singular-plural forms of nouns since Thai is an isolating language, so the forms of Thai words are never changed: unlike English ones. Online lessons on simple sentences with 'be', capitalization, punctuation, pronouns, and articles are posted on LMS platform so that the students can learn at their own pace anywhere and anytime. The students are supposed to spend at least four hours a week for their independent study.

A variety of class activities are organized in order to give the students more opportunities in writing with the emphasis on accuracy and to increase student engagements with fun activities in pairs or in groups. Copying activities, parallel writing, jumbled sentences, error recognition and correction, writing for fun (describing photos, lost and found, jigsaw stories, etc.) and online games such as Kahoot are applied in class.

The questionnaire is used to find out students' attitudes towards the flipped classroom. There are two parts: personal data and students' attitudes which were five scales in the questionnaire together with short answers. The students were asked to complete the questionnaire after completing the posttest.

The data collection procedures were summarized in Figure 1 below.

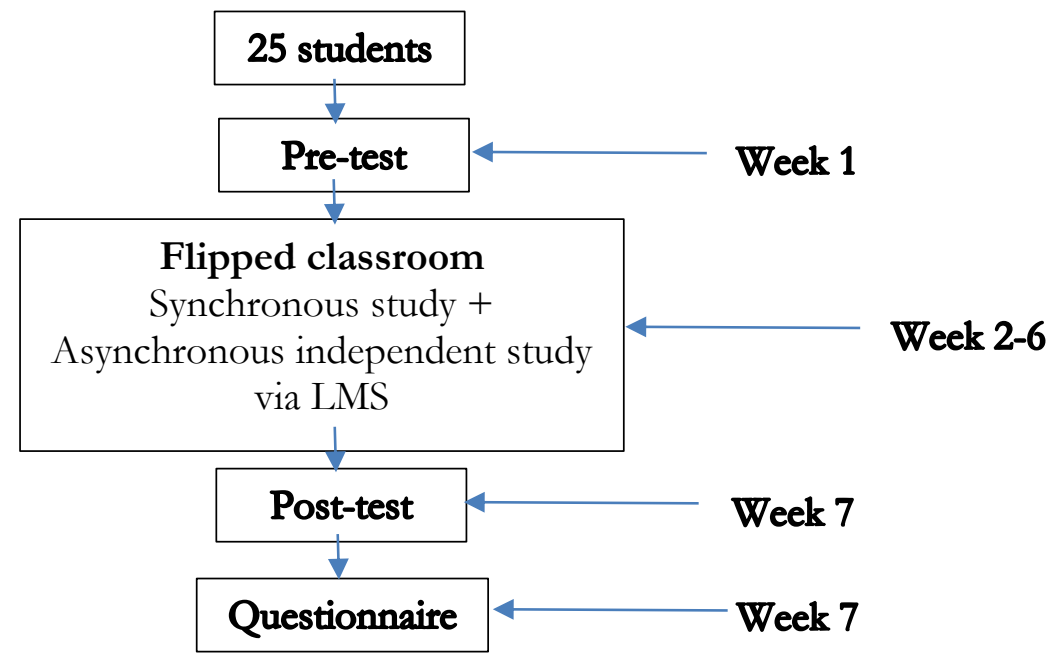

FIGURE 1. Research Design 


\section{Benny Kurnianto}

In this study, the data was analyzed quantitatively and qualitatively. Some statistics were analyzed using SPSS program. A paired t-test was used to compare the mean scores of the pre-test and post-test in order to determine the students' achievement in their sentence writing.

\section{RESULTS AND DISCUSSION}

\section{The Elimination of Anticipated Written Errors from L1 Interference with the Flipped Classroom.}

To determine if the flipped classroom helps eliminate anticipated written errors from L1 interference, the means of the pre-test and post-test were analyzed quantitatively. Before the commencement of the study, all of the students completed the pre-test on simple sentence with 'be'. Each student produced 30 simple sentences, so 750 sentences in total. However, in the pre-test, 212 test items went blank; only 538 sentences were produced. The possible reasons for this phenomenon are 'a lack of vocabulary' and 'being afraid of making mistakes'. In the post-test, on the other hand, only 36 test items went blank; 714 sentences were produced. It can be implied that the students' vocabulary was improved and expanded, and they were more willing to take risks in writing sentences.

In accordance to the simple sentences from pre- and post-tests, 5 of the most common written errors from L1 interference at a sentence level are 1) articles, 2) capital letter, 3) punctuation, 4) nouns, and 5) subject-verb agreement respectively as shown in Table 1 . The finding is similar to the previous studies investigated by Prapawadee (2005), Bennui, (2008), Sittirak (2015) and Roongsitthichai et al. (2019). It might be slightly different due to objectives of writing (to write a simple sentence with verb to be, for instance), levels of writing (word, sentence, paragraph, or essay), genres of writing, etc.

TABLE 4. 5 Common Written Errors from L1 Interference at a Sentence Level

\begin{tabular}{|c|c|c|c|}
\hline \multirow[t]{2}{*}{ Error types } & \multicolumn{2}{|c|}{$\begin{array}{c}\text { Frequency \& } \\
\text { Percentage }\end{array}$} & \multirow[t]{2}{*}{ Examples } \\
\hline & Pre-test & Post-test & \\
\hline $\begin{array}{l}\text { Articles } \\
\text { [omission of a, an, the] }\end{array}$ & $\begin{array}{c}113 \\
(21 \%)\end{array}$ & $\begin{array}{c}105 \\
(14.71 \%)\end{array}$ & $\begin{array}{ll}\text { - } & \wedge \text { Puppy is } 5 \text { months old. } \\
\text { - } & \text { We are interested in }{ }^{\wedge} \text { Chinese language. } \\
\text { - } & \wedge \text { weather is good. } \\
\text { - } & \wedge \text { Cat is under }{ }^{\wedge} \text { table. } \\
\text { - } & \wedge \text { Orange is sweet. }\end{array}$ \\
\hline Capital letters & $\begin{array}{c}44 \\
(8.18 \%)\end{array}$ & $\begin{array}{c}50 \\
(7 \%)\end{array}$ & $\begin{array}{l}\text { - My name is khajorsak singjanusong. } \\
\text { - } \quad \text { that flower is white. } \\
\text { - An English test is on sunday. } \\
\text { - } \quad \text { A Movie I like is low season. } \\
\text { - } \quad \text { They are chinese people. }\end{array}$ \\
\hline $\begin{array}{l}\text { Punctuation } \\
\text { [no period] }\end{array}$ & $\begin{array}{c}28 \\
(5.20 \%)\end{array}$ & $\begin{array}{c}17 \\
(2.38 \%)\end{array}$ & $\begin{array}{l}\text { - He is sick } \\
\text { - } \text { My mum is kind } \\
\text { - } M y \text { favorite movie is The Nun } \\
\end{array}$ \\
\hline $\begin{array}{l}\text { Nouns } \\
\text { [singular-plural forms] }\end{array}$ & $\begin{array}{c}19 \\
(3.53 \%)\end{array}$ & $\begin{array}{c}15 \\
(2.10 \%)\end{array}$ & $\begin{array}{l}\text { - A puppy is five month old. } \\
\text { - Two bicycle are under the tree. } \\
\text { - Lek and Yai are friend. }\end{array}$ \\
\hline Subject-Verb agreement & $\begin{array}{c}5 \\
(0.93 \%)\end{array}$ & $\begin{array}{c}3 \\
(0.42 \%)\end{array}$ & $\begin{array}{l}\text { - They is chinese. } \\
\text { - Lek and Yai is friend. } \\
\text { - There is two bicycles under tree. }\end{array}$ \\
\hline $\begin{array}{l}\text { Total number of } \\
\text { sentences produced }\end{array}$ & 538 & 714 & \\
\hline
\end{tabular}


In order to discover whether the written errors were reduced, the percentage of the occurrences of five error types were compared by using a paired sample t-test as shown in TABLE 2 . The results demonstrate that the percentage of written errors in the post-test was lower than that obtained from the pre-test. It indicates that the errors were reduced after learning with the flipped classroom.

TABLE 5. A Comparison of the Percentage of the Occurrences of Errors between the Pre- and Post-Tests

\begin{tabular}{lccccc}
\hline & N & $\bar{X}$ & S.D. & t & Sig \\
\hline Pre-test & 5 & 7.77 & 7.85 & $2.37 *$ & .0384 \\
\hline Post-test & 5 & 5.32 & 5.79 & & \\
\hline
\end{tabular}

Regarding the mean scores of the pre- and post-tests, they were compared by using a paired sample t-test. Table 6 presents that the mean score of the post-test was higher than that of the pretest. As evidenced by the significant difference at the level of .001. It clearly illustrates that the flipped classroom covering online lessons and class activities was effective.

TABLE 6. A Comparison of the Scores between the Pre- and Post-Tests

\begin{tabular}{lccccc}
\hline & N & $\bar{X}$ & S.D. & t & Sig \\
\hline Pre-test & 25 & 32.48 & 11.37 & $9.57^{*}$ & .0000 \\
\hline Post-test & 25 & 50.14 & 5.38 & & \\
\hline
\end{tabular}

\section{Students' Attitudes towards the Flipped Classroom}

To examine the students' attitudes towards the flipped classroom, the data from the questionnaire was used. 24 students completed the questionnaire. $87.5 \%$ of the students was female, and $12.5 \%$ of them was male. Also, $75 \%$ of them has been studying English for more than 10 years. As shown in the bar graph below more than half of the students agree that they need more class time, so two-hour session per week is not enough.

\section{I need more class time. ฉันต้องการเวลาเรียนในชั้นเรียนมากกว่านี้ คำตอบ 24 ข้อ}

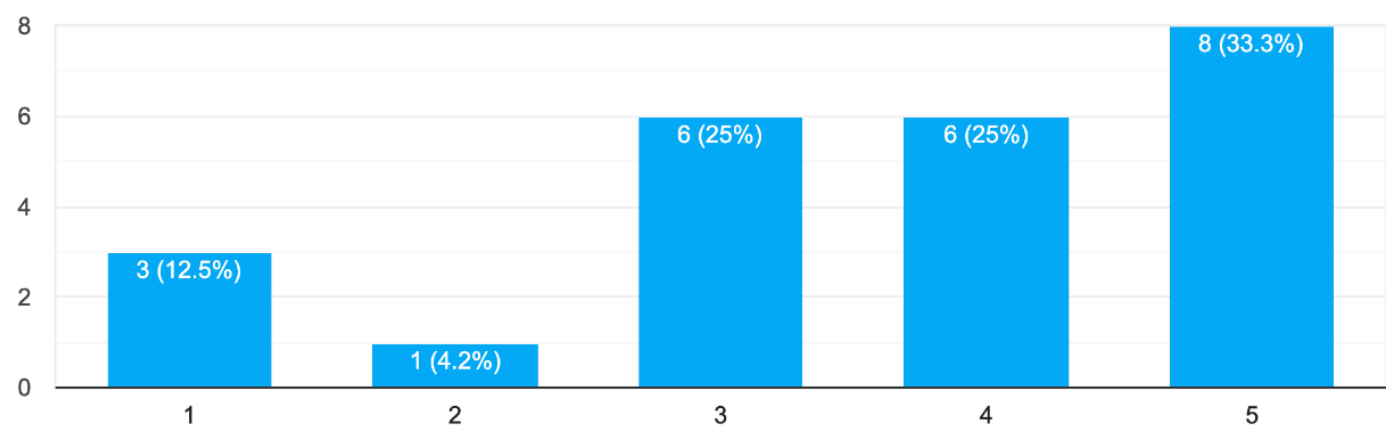

As for the class activities, the majority of the students (95.9\%) love participating in class activities, and all of the students participate in class activities. They prefer to work in groups (91.6\%), in pair $(83.3 \%)$, and own their own $(37.5 \%)$ respectively. In addition, $95.9 \%$ of the students like the lecture in class. The most favorite class activity is competitive games that the students do exercises in groups and then discuss the answers with the whole class to find out the winner team.

Concerning asynchronous independent study, the majority of the students $(95.9 \%)$ agree that the online lessons are useful for them to do class activities. $58.3 \%$ of the students spend $1-2$ hours a week for their self-study, and 33.3\% spend 3-4 hours a week as planned while only two students never do. As a whole, $75 \%$ of students like the flipped classroom. It can be concluded that students had positive attitudes towards the flipped classroom because of a variety of class activities promoting cooperative learning and self-study lessons that they can learn at their own pace reducing anxiety or affective filter. 


\section{Benny Kurnianto}

Furthermore, the results are in harmony with the previous studies examined by Thaichay and Sitthitikul (2016) that flipped classrooms can help improve students' English accuracy and promote learning environment.

\section{CONCLUSION}

The findings of the study support the use of flipped classrooms due to their benefits that students' English proficiency can be improved with positive attitudes. Teachers need to pay more attention on a variety of class activities in order to support students' learning styles, and the teachers should emphasize on interesting lessons to promote students' enthusiasm for autonomous learning.

\section{ACKNOWLEDGEMENTS}

My appreciation extends to the faculty of International Studies, Prince of Songkla University, Phuket campus for the financial support which allows me to participate in this paper presentation. Also, I would like to extend my appreciation to the lecturers and students whose cooperation made my study possible. Additionally, my special thanks are extended to Mr. Philip John Galloway, a lecturer in the department of foreign languages, the faculty of International Studies, Prince of Songkla University in helping proofread my paper and to Universitas Islam Malang in giving me a good opportunity to join this event: the first international conference on English Language Teaching.

\section{REFERENCES}

Bennui, Pairote. (2008). A Study of L1 Intereference In the Writing of Thai EFL Students. Malaysian Journal of ELT Research, 4, 72-102

Kaewwichian, D. and Jaturapitakkul, N. (2018). Self-Perception of English Proficiency of Thai Lower Secondary EFL Teachers. rEFLections, 25, 21-41.

Kanchai, Thebporn. (2019). Thai EFL University Lecturers' Viewpoints towards Impacts of the CEFR on their English Language Curricula and Teaching Practice. NIDA Journal of Language and Communication, 24 (35), 23-47.

Peachey, Nik. (2020). The Flipped Classroom for English Language Teaching. Retrieved September 15, 2020, from https://elt.oup.com/elt/teachers/generalcontent/focus-papers/oup-focusflipped-classroom.pdf?cc $=$ th\&selLanguage $=$ th\&mode $=$ hub.

Prapawadee, Napacha. (2005). The Effects of Formal and Conversational Thai Explanations in Grammatical Computer-Assisted Language Learning (CALL) Packages on Students' Attitudes and Learning Outcomes. (Unpublished master thesis). Prince of Songkla University, Hat Yai Campus, Songkhla, Thailand.

Richards, Jack and Schmidt, Richard. (2010). Longman Dictionary of Language Teaching and Applied Linguistics. Malaysia: Pearson Education.

Roongsitthichai, Atthaporn et al. (2019). Error Analysis in English Abstracts Written by Veterinary Students in Northeast Thailand. Chophayom Journal, 30(3), 21-30.

Sitsungnern, Chonnasit. (2017). Flipped Classroom: Learning Skill in Century 21st. Journal of MCU Social Science Review. 6(2), 171-182.

Sittirak, Nantana. (2015). Grammar-Translation Method in an EFL Class in Thailand: A Glance at an English Song's Lyrics. Journal of Education Thaksin University, 15(2), 30-47.

Srichailard, Uraiwan and Srichailard, Panuwat. (2019). The Development of a Flipped Classroom Teaching Model Using Think-pair-share and Project-based Learning. Journal of Industrial Education, 18(1), 50-58.

Thaichay, Thanachok and Sitthitikul, Pragasit. (2010). Effects of the Flipped Classroom Instruction on Language Accuracy and Learning Environment: A Case Study of Thai EFL UpperSecondary School Students. Rangsit Journal of Educational Studies, 3(2), 35-64.

Thai English skills dip for third year. (2019, November). Retrieved September 15, 2020, from http://www.en.moe.go.th/enMoe2017/index.php/articles/488-thai-english-skills-dip-forthird-year. 
Waluyo, Budi. (2019). Examining Thai First-Year University Students' English Proficiency on CEFR Levels. The New English Teacher, 13 (2), 51-71. 